\title{
Tocopherol Contents of Pulp Oils Extracted from Ripe and Unripe Avocado Fruits Dried by Different Drying Systems
}

\author{
Kashif Ghafoor ${ }^{1 *}$, Nurhan Uslu², Fahad Al-Juhaimi ${ }^{1}$, Elfadıl E.Babiker ${ }^{1}$, \\ Isam A.Mohammed Ahmed ${ }^{1}$, Mehmet Uğur Yıldız ${ }^{3}$, Omer N. Alswahmi ${ }^{1}$, and \\ Mehmet Musa Özcan² \\ 1 Department of Food Science \& Nutrition, College of Food and Agricultural Sciences, King Saud University, Riyadh-SAUDI ARABIA
${ }^{2}$ Department of Food Engineering, Faculty of Agriculture, Selcuk University, 42031 Konya, TURKEY
${ }^{3}$ Agriculture Engineering, Istanbul, TURKEY
}

Abstract: The tocopherol contents of unripe and ripe avocado fruit oil extracted from Pinkerton, Hass and Fuerte varieties were determined after drying fruit using air, microwave or oven drying methods. The $\alpha$ tocopherol content changed between $13.70 \mathrm{mg} / 100 \mathrm{~g}$ (microwave-dried) and $28.06 \mathrm{mg} / 100 \mathrm{~g}$ (air-dried) in oil from unripe Pinkerton fruit; between $14.86 \mathrm{mg} / 100 \mathrm{~g}$ (microwave-dried) and $88.12 \mathrm{mg} / 100 \mathrm{~g}$ (fresh) in oil from unripe Hass fruit and between $13.31 \mathrm{mg} / 100 \mathrm{~g}$ (microwave-dried) and $17.35 \mathrm{mg} / 100 \mathrm{~g}$ (oven-dried) in oil from unripe Fuerte fruit. The $\alpha$-tocopherol contents in oil from ripe Fuerte fruit changed between 13.21 $\mathrm{mg} / 100 \mathrm{~g}$ (fresh) and $17.61 \mathrm{mg} / 100 \mathrm{~g}$ (oven-dried). In addition, $\gamma$-tocopherol contents varied between 11.55 $\mathrm{mg} / 100 \mathrm{~g}$ (air-dried) and $14.61 \mathrm{mg} / 100 \mathrm{~g}$ (microwave-dried) unripe "Pinkerton" fruit; between $11.52 \mathrm{mg} / 100$ $\mathrm{g}$ (air-dried) and $15.01 \mathrm{mg} / 100 \mathrm{~g}$ (fresh) in unripe Hass fruit and between $12.17 \mathrm{mg} / 100 \mathrm{~g}$ (air-dried) and $15.27 \mathrm{mg} / 100 \mathrm{~g}$ (microwave-dried) unripe Fuerte fruit. The $\gamma$-tocopherol contents ranged from $12.71 \mathrm{mg} / 100$ $\mathrm{g}$ (fresh) to $17.40 \mathrm{mg} / 100 \mathrm{~g}$ (oven-dried) in ripe Hass fruit; from $10.29 \mathrm{mg} / 100 \mathrm{~g}$ (fresh) and $17.20 \mathrm{mg} / 100 \mathrm{~g}$ (microwave-dried) ripe Fuerte fruit. $\alpha$-, $\beta$-, $\gamma$ - and $\delta$-tocopherols could not be detected in ripe fresh Pinkerton fruit. In general, $\beta$ - and $\delta$-tocopherol could not be detected in most of the unripe and ripe avocado fruit oils. $\alpha$-Tocopherol and $\gamma$-tocopherol contents of dried ripe Fuerte fruit oils were found to be higher compared to those of dried unripe Fuerte fruits.

Key words: avocado varieties, fruit drying, fruit oil, tocopherols, HPLC

\section{Introduction}

Fruit from avocado (Persea americana Mill.) tree has gained significance from nutritional and commercial aspects. Among different tropical and subtropical fruits, avocado fruit has prominent market value and it is cherished due to high nutritional value, especially due to, its edible fibre and lipid contents ${ }^{1,2}$. Presence of high levels of bioactive compounds, including vitamin $\mathrm{E}$, carotenoids and soluble phenolics is also being recognized in different studies $^{3-6)}$. The current trends of consumption of avocado fruit include as vegetable in the form of salads along with onions and cheese, as a soup containing salt and pepper and as canned products ${ }^{7}$. Medicinal uses of avocado fruit also include treatment of hypercholesterolemia, hypertension, type 2 diabetes mellitus, and dyslipidemia. It is gener- ally regarded as beneficial in maintaining cardiovascular health ${ }^{8,9)}$. Lu et al. ${ }^{10)}$ observed inhibition of prostate cancer cell growth using a lipophilic extract of avocado fruit.

Hence, different uses of avocado fruit require application of appropriate processing techniques that maintain its functional properties in the final product. Drying is a commonly used and well-known postharvest technology aimed at increasing the shelf life of fruits or vegetables, preserving their quality and stability by reducing water activity and moisture content thereby avoiding spoilage and contamination during storage and making possible their utilization in different products including spices, folk medicine ${ }^{11}$. The content of avocado oil is used as an indicator of the fruit maturation stage prior to harvest ${ }^{1)}$ and the ripening stage of avocado fruit and the variety can influence the

\footnotetext{
*Correspondence to: Kashif Ghafoor, Department of Food Science \& Nutrition, College of Food and Agricultural Sciences, King Saud University, Riyadh-SAUDI ARABIA

E-mail: kghafoor@ksu.edu.sa

Accepted September 28, 2020 (received for review August 24, 2020)

Journal of Oleo Science ISSN 1345-8957 print / ISSN 1347-3352 online

http://www.jstage.jst.go.jp/browse/jos/ http://mc.manusriptcentral.com/jjocs
} 
composition and contents of different nutrients in avocado $\mathrm{oil}^{2}$. It would be interesting to carry out detailed analytical study of tocopherols in relation of fruit maturation, varieties and drying method used to process the avocado fruit. Therefore, current study was aimed at characterization of tocopherol contents of unripe and ripe avocado fruit oils extracted from three different varieties (Fuerte, Hass and Pinkerton)after drying using three distinctive techniques, namely air-, microwave- and oven-drying methods.

\section{Material and Methods \\ 2.1 Material}

Avocado fruits were harvested from Fuerte, Hass and Pinkerton varieties at two different maturity stages (unripe and ripe)in Antalya, Turkey. Avocado fruits were cut to separate pulp from seed and peel fractions.

\subsection{Methods}

\subsubsection{Samples}

Avocado fruit pulp samples from each variety (ripe and unripe) were divided into 4 groups:

Group 1: Control group consisting of untreated pulp

Group 2: Room temperature dried pulp

Group 3: Microwave oven ( $540 \mathrm{~W}, 15 \mathrm{~min}$ ) dried fruit pulp

Group 4: Oven $\left(60^{\circ} \mathrm{C}, 19 \mathrm{~h}\right)$ dried pulp

These experimental conditions were selected after preliminary drying treatments in which the final pulp moisture content was maintained at less than $5 \%$.

\subsubsection{Analysis for tocopherol contents}

Quantification for tocopherol contents was carried out following Spica et al. ${ }^{12)}$ procedure. Oil was extracted from pulp samples from different varieties using Soxhlet system and $0.1 \mathrm{~g}$ of it was mixed with $5 \mathrm{~mL}$ of $n$-hexane followed by filtration using $0.45 \mu \mathrm{m}$ nylon filter. Tocopherol analyses was accomplishing using a Shimadzu-HPLC system that consisted of a PDA detector and LiChroCART Silica 60 (4.6 $\times 250 \mathrm{~mm}, 5 \mu$; Merck, Darmstadt, Germany) column. An isocratic chromatographic separation of tocopherols was carried out using $0.7 \%$ propan- 2 -ol in $n$-hexane as mobile phase which set to flow at $0.9 \mathrm{~mL} / \mathrm{min}$ rate. The sample injection volume was set as $20 \mu \mathrm{L}$ and detection and identification of peaks was carried out at 295 and $330 \mathrm{~nm}$ wavelength set at PDA detector following a 30 min running time for each sample. Chromatography standards were prepared using 0-100 mg of $\alpha, \beta, \gamma$ and $\delta$-tocopherols per $1 \mathrm{~L}$ of solutions prepared following same procedure as explained for oil samples. All the chemical used were of analytical grade and each treatment and measurement of tocopherol sample was carried out in triplicates.

\subsection{Statistical analyses}

The experiments were carried out according to a com- plete randomized split plot block design and obtained data was subjected to analysis of variance (ANOVA) using JMP software (v 9.0, SAS Inst. Inc., Cary, N.C.U.S.A) . All analytical measurements were carried out in triplicates and results were expressed as means \pm standard deviations (MSTAT C) for each independent avocado fruit variety sample $^{13)}$.

\section{Results and Discussion}

Tocopherol contents of oils obtained from fruit pulp from three different unripe and ripe avocado varieties ("Hass", "Fuerte" and "Pinkerton") dried using different drying systems are presented in Table 1. The $\alpha$-tocopherol contents changed between $13.70 \mathrm{mg} / 100 \mathrm{~g}$ (Microwave) and $28.06 \mathrm{mg} / 100 \mathrm{~g}$ (Air drying) in unripe "Pinkerton" fruit pulp oil and between $14.86 \mathrm{mg} / 100 \mathrm{~g}$ (Microwave) and 88.12 mg/100 g (Fresh)in unripe "Hass" fruit oils. In addition, $\alpha$-tocopherol contents of ripe "Pinkerton" fruit oil were determined between 0.0 (fresh and microwave) and 19.40 $\mathrm{mg} / 100 \mathrm{~g}$ (Oven) while $\alpha$-tocopherol contents of ripe "Hass" fruit oil varied between 0.0 (microwave and oven) and 53.05 $\mathrm{mg} / 100 \mathrm{~g}$ (fresh). Similarly, $\alpha$-tocopherol contents was determined between $13.31 \mathrm{mg} / 100 \mathrm{~g}$ (microwave) and 17.35 $\mathrm{mg} / 100 \mathrm{~g}$ (oven) in unripe "Fuerte" fruit pulp oil and between $13.21 \mathrm{mg} / 100 \mathrm{~g}$ (fresh) and $17.61 \mathrm{mg} / 100 \mathrm{~g}$ (oven) in ripe "Fuerte" fruit oils. In addition, $\gamma$-tocopherol contents of unripe "Pinkerton" fruits varied between 11.55 $\mathrm{mg} / 100 \mathrm{~g}$ (air) and $14.61 \mathrm{mg} / 100 \mathrm{~g}$ (microwave) while that of ripe "Pinkerton" fruit oils were determined between 11.55 $\mathrm{mg} / 100 \mathrm{~g}$ (air) and $15.57 \mathrm{mg} / 100 \mathrm{~g}$ (oven). Additionally, $\gamma$-tocopherols of unripe "Hass" fruit oils changed between $11.52 \mathrm{mg} / 100 \mathrm{~g}$ (air) and $15.01 \mathrm{mg} / 100 \mathrm{~g}$ (fresh) while that of ripe "Hass" fruit oils ranged from $12.71 \mathrm{mg} / 100 \mathrm{~g}$ (fresh) to $17.40 \mathrm{mg} / 100 \mathrm{~g}$ (oven). The $\gamma$-tocopherol contents of unripe "Fuerte" fruit oils were detected between $12.17 \mathrm{mg} / 100 \mathrm{~g}$ (air) and $15.27 \mathrm{mg} / 100 \mathrm{~g}$ (microwave) while that of ripe "Fuerte" oils varied between $10.29 \mathrm{mg} / 100 \mathrm{~g}$ (fresh) and $17.20 \mathrm{mg} / 100 \mathrm{~g}$ (microwave). The $\alpha-, \beta-, \gamma-$ and $\delta$-tocopherols in ripe fresh "Pinkerton" oil were not detected. In general, $\beta$ - and $\delta$-tocopherols could not be detected in most of the oil samples from unripe and ripe avocado fruit. Drying affected tocopherol contents of avocado fruit pulp depending on the varieties and maturation stages. The $\alpha$ and $\gamma$-tocopherol contents of ripe "Fuerte" fruits dried by air, microwave and oven were found to be higher compared to their values for unripe "Fuerte" fruits dried using same drying methods. $\beta$ - and $\delta$-tocopherols were observed in unripe "Fuerte" oil dried by air drying. Statistically significant differences were identified among tocopherol contents of ripe and unripe avocado fruit oils $(p<0.05)$ (Fig. 1a-v). Peraza-Magallanes et al. ${ }^{14)}$ reported that fresh "Hass" pulp oil contained 45.02- 
Table 1 Tocopherol contents of oils from avocado fruit pulp oils $(\mathrm{mg} / 100 \mathrm{~g})$ from ripe and unripe fruits from different varieties dried using different techniques.

\begin{tabular}{|c|c|c|c|c|c|c|}
\hline Maturity & Process & Variety & $\alpha-T$ & $\beta-\mathrm{T}$ & $\gamma-\mathrm{T}$ & $\delta-\mathrm{T}$ \\
\hline \multirow{12}{*}{ Unripe } & Fresh & Pinkerton & $16.09 \pm 0.23^{*^{c}}$ & - & - & - \\
\hline & Air-drying & Pinkerton & $28.06 \pm 0.00^{\mathrm{a} * *}$ & $14.50 \pm 0.03$ & $11.55 \pm 0.02^{\mathrm{c}}$ & - \\
\hline & Microwave drying & Pinkerton & $13.70 \pm 0.00^{\mathrm{d}}$ & - & $14.61 \pm 0.02^{\mathrm{a}}$ & $13.05 \pm 0.01$ \\
\hline & Oven drying & Pinkerton & $18.49 \pm 0.19^{b}$ & - & $12.87 \pm 0.48^{\mathrm{b}}$ & - \\
\hline & Fresh & Hass & $88.12 \pm 0.42^{\mathrm{a}}$ & $11.29 \pm 0.00^{b}$ & $15.01 \pm 0.10^{\mathrm{a}}$ & $11.00 \pm 0.03$ \\
\hline & Air-drying & Hass & $15.15 \pm 0.36^{\mathrm{c}}$ & $12.65 \pm 0.00^{\mathrm{a}}$ & $11.52 \pm 0.01^{\mathrm{c}}$ & - \\
\hline & Microwave drying & Hass & $14.86 \pm 0.05^{\mathrm{d}}$ & - & $14.90 \pm 0.02^{\mathrm{b}}$ & - \\
\hline & Oven drying & Hass & $16.66 \pm 0.00^{\mathrm{b}}$ & - & - & - \\
\hline & Fresh & Fuerte & $14.08 \pm 0.00^{\mathrm{bc}}$ & - & - & $11.81 \pm 0.00^{\mathrm{a}}$ \\
\hline & Air-drying & Fuerte & $14.35 \pm 0.03^{\mathrm{b}}$ & $11.52 \pm 0.00$ & $12.17 \pm 0.02^{\mathrm{c}}$ & $8.68 \pm 0.00^{\mathrm{b}}$ \\
\hline & Microwave drying & Fuerte & $13.31 \pm 0.02^{\mathrm{c}}$ & - & $15.27 \pm 0.04^{\mathrm{a}}$ & - \\
\hline & Oven drying & Fuerte & $17.35 \pm 0.10^{\mathrm{a}}$ & - & $14.03 \pm 0.10^{\mathrm{b}}$ & - \\
\hline \multirow{12}{*}{ Ripe } & Fresh & Pinkerton & - & - & - & - \\
\hline & Air-drying & Pinkerton & $14.54 \pm 0.02^{\mathrm{b}}$ & - & $11.55 \pm 0.03^{\mathrm{c}}$ & - \\
\hline & Microwave drying & Pinkerton & - & - & $12.76 \pm 0.02^{\mathrm{b}}$ & $10.26 \pm 0.00$ \\
\hline & Oven drying & Pinkerton & $19.40 \pm 0.08^{\mathrm{a}}$ & - & $15.57 \pm 0.03^{\mathrm{a}}$ & - \\
\hline & Fresh & Hass & $53.05 \pm 0.32^{\mathrm{a}}$ & $11.87 \pm 0.03^{b}$ & $12.71 \pm 0.04^{\mathrm{d}}$ & $8.71 \pm 0.00$ \\
\hline & Air-drying & Hass & $20.38 \pm 0.37^{\mathrm{b}}$ & - & $14.44 \pm 0.12^{\mathrm{c}}$ & - \\
\hline & Microwave drying & Hass & - & $12.09 \pm 0.00^{\mathrm{a}}$ & $15.32 \pm 0.03^{\mathrm{b}}$ & - \\
\hline & Oven drying & Hass & - & - & $17.40 \pm 0.13^{\mathrm{a}}$ & - \\
\hline & Fresh & Fuerte & $13.21 \pm 0.00^{\mathrm{d}}$ & - & $10.29 \pm 0.01^{\mathrm{d}}$ & $8.40 \pm 0.03$ \\
\hline & Air-drying & Fuerte & $15.22 \pm 0.25^{\mathrm{b}}$ & - & $12.31 \pm 0.00^{\mathrm{c}}$ & - \\
\hline & Microwave drying & Fuerte & $14.42 \pm 0.08^{\mathrm{c}}$ & - & $17.20 \pm 0.03^{\mathrm{a}}$ & - \\
\hline & Oven drying & Fuerte & $17.61 \pm 0.26^{\mathrm{a}}$ & - & $14.27 \pm 0.30^{b}$ & - \\
\hline
\end{tabular}

*standard deviation; ** values within each column followed by different letters are significantly different at $p<0.05$.

$50.66 \mu \mathrm{g} / \mathrm{g}$ of $\alpha$-tocopherol. The $\alpha$-tocopherol contents in the unsaponifiable fraction of "Fortuna" avocado pulp oils obtained after using different pulp drying techniques and extraction methods changed between $0.55 \%$ and $1.25 \%$. In general, $\alpha$-tocopherol losses can be associated with oxidative stress ${ }^{15)}$. Saldeen and Saldeen ${ }^{16)}$ reported that the mixture of $\alpha-, \gamma-$, and $\delta$-tocopherols showed better antioxidant and anti-inflammatory effects in comparison to $\alpha$-tocopherol using animal models in a limited number of preliminary clinical investigations. Tocopherols are commonly used as antioxidants because they donate hydrogen from the hydroxyl group to the peroxyl radical ${ }^{17)}$. Microwave technologies is one of the new techniques for drying of fruits and their pulps and it was furthermore reported to prevent browning of avocado pulp during blanching process $^{18)}$. The $\alpha$-tocopherol is considered as a scavenger of free radicals, thereby inhibiting the oxidation of both fats and phytosterols and persevering the oil quality over longer period of time ${ }^{15,19,20-22)}$. Results presented in the current study vary from those reported in literature values and these variations can be attributed to the maturation stage of avocado fruit, geographic location, climatic factors, genetic structure and agricultural factors. Individual tocopherols showed marked variations in terms of their sensitivities to different drying methods. Most of the drying techniques caused reduction in $\alpha$-tocopherol contents weather in ripe or unripe fruit pulp from "Hass" and "Pinkerton" avocado whereas it showed significant increments in "Fuerte" pulp after drying.

\section{Conclusion}

The $\alpha$-tocopherol contents were generally higher in pulp oil from unripe fruit in comparison to ripe ones. "Hass" variety fruit pulp showed higher $\alpha$-tocopherol contents than other two varieties. Variations in tocopherols sensitivity to drying process in different pulp from different avocado fruits may also depend on the structure of each type of tocopherols and such variations can be related with the structural differences among the four different kinds of tocopherols that may determine their stability. Further 

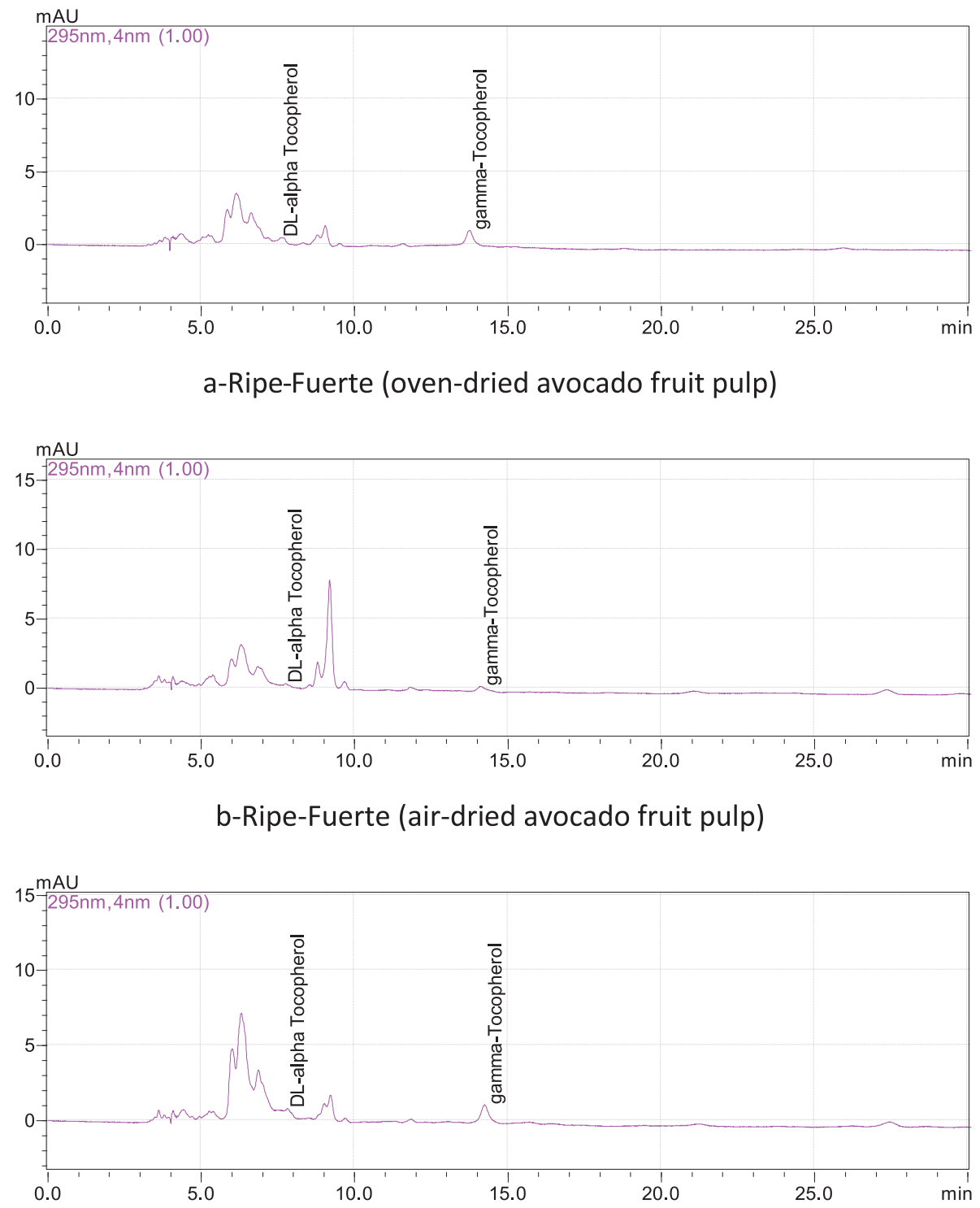

c-Ripe-Fuerte (microwave-dried avocado fruit pulp)

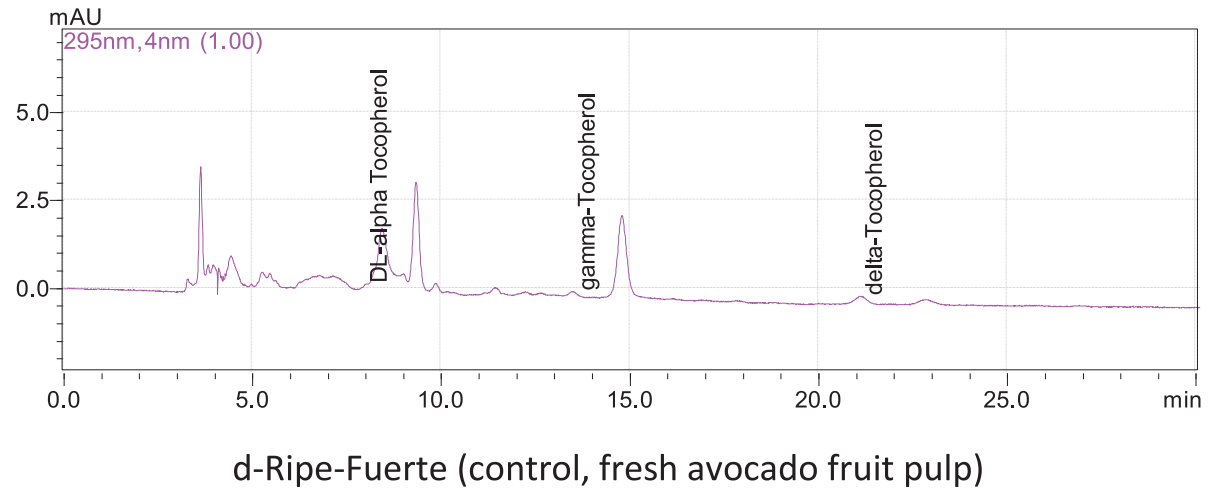

Fig. 1 Tocopherol chromatograms of oils from pulp of ripe and unripe avocado fruits from three different varieties and as affected by drying of pulp. 

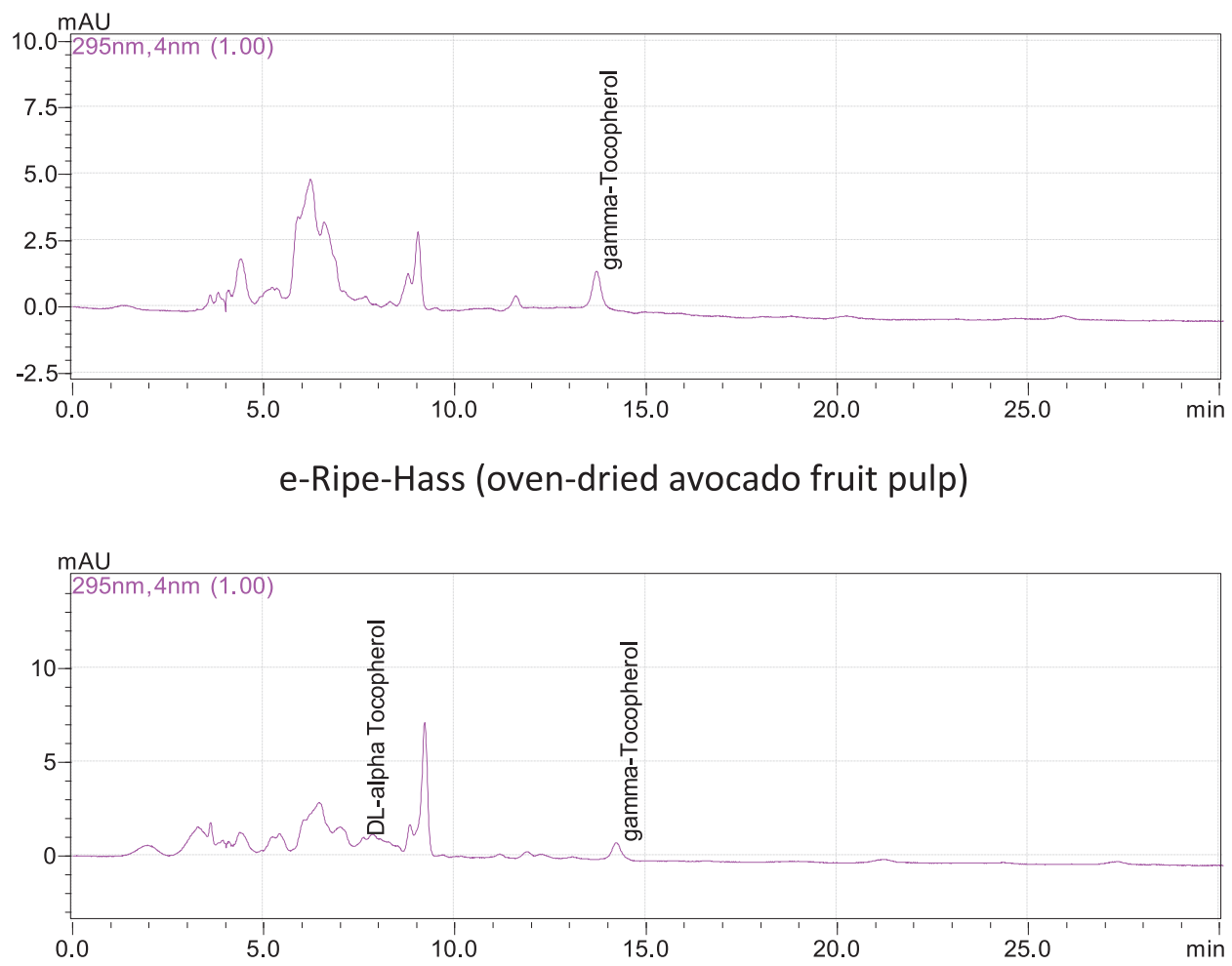

f-Ripe-Hass (air-dried avocado fruit pulp)

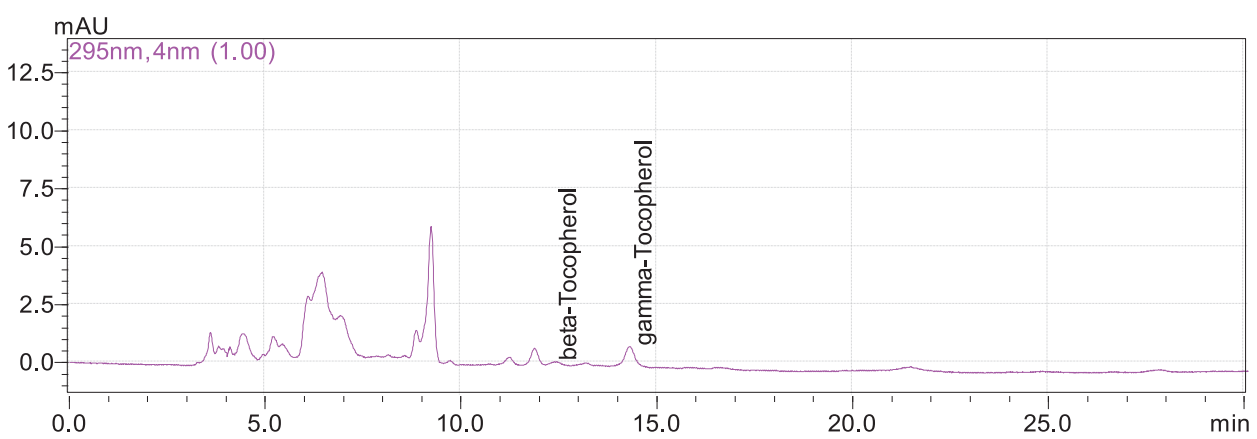

g-Ripe-Hass (microwave-dried avocado fruit pulp)

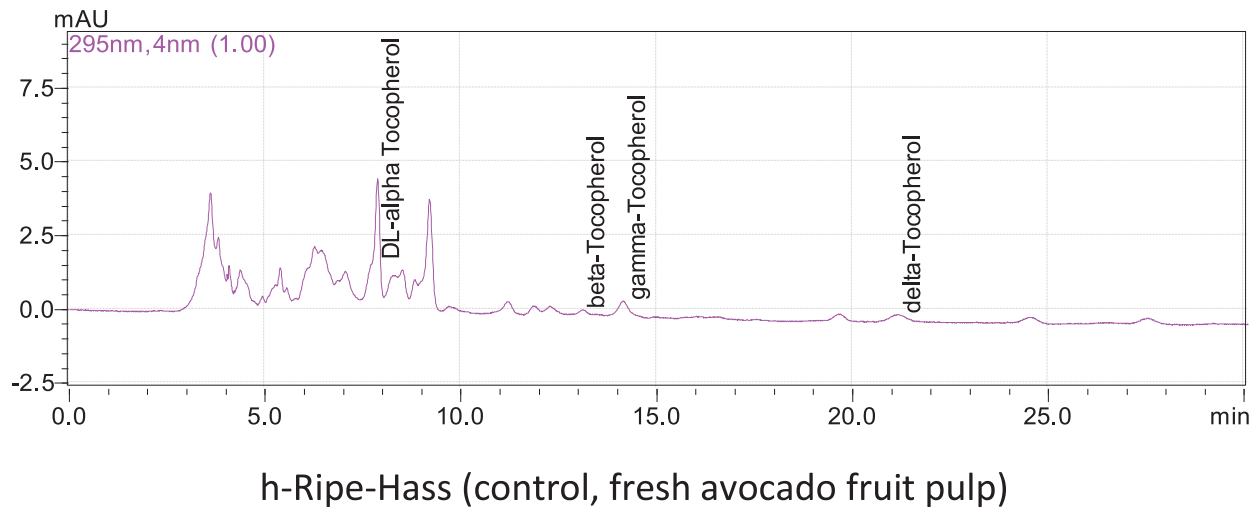

Fig. 1 Continued. 


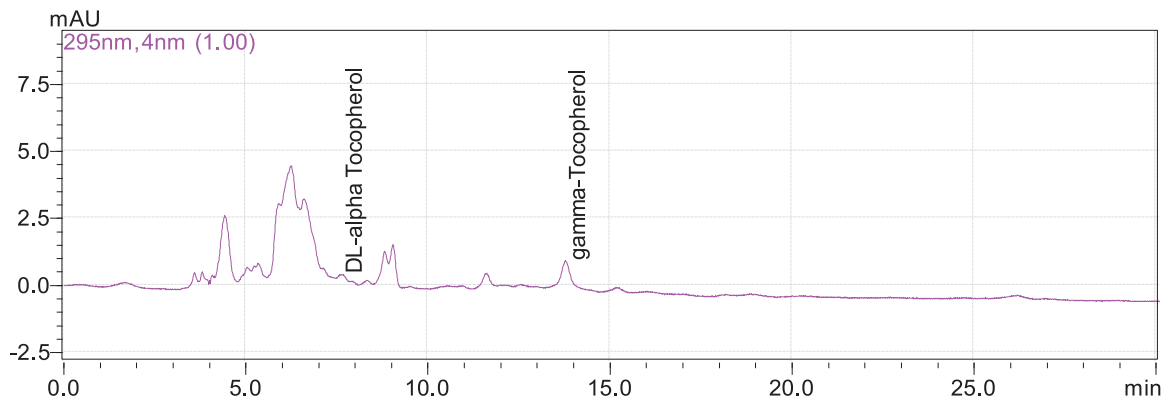

i-Ripe-Pinkerton (oven-dried avocado fruit pulp)
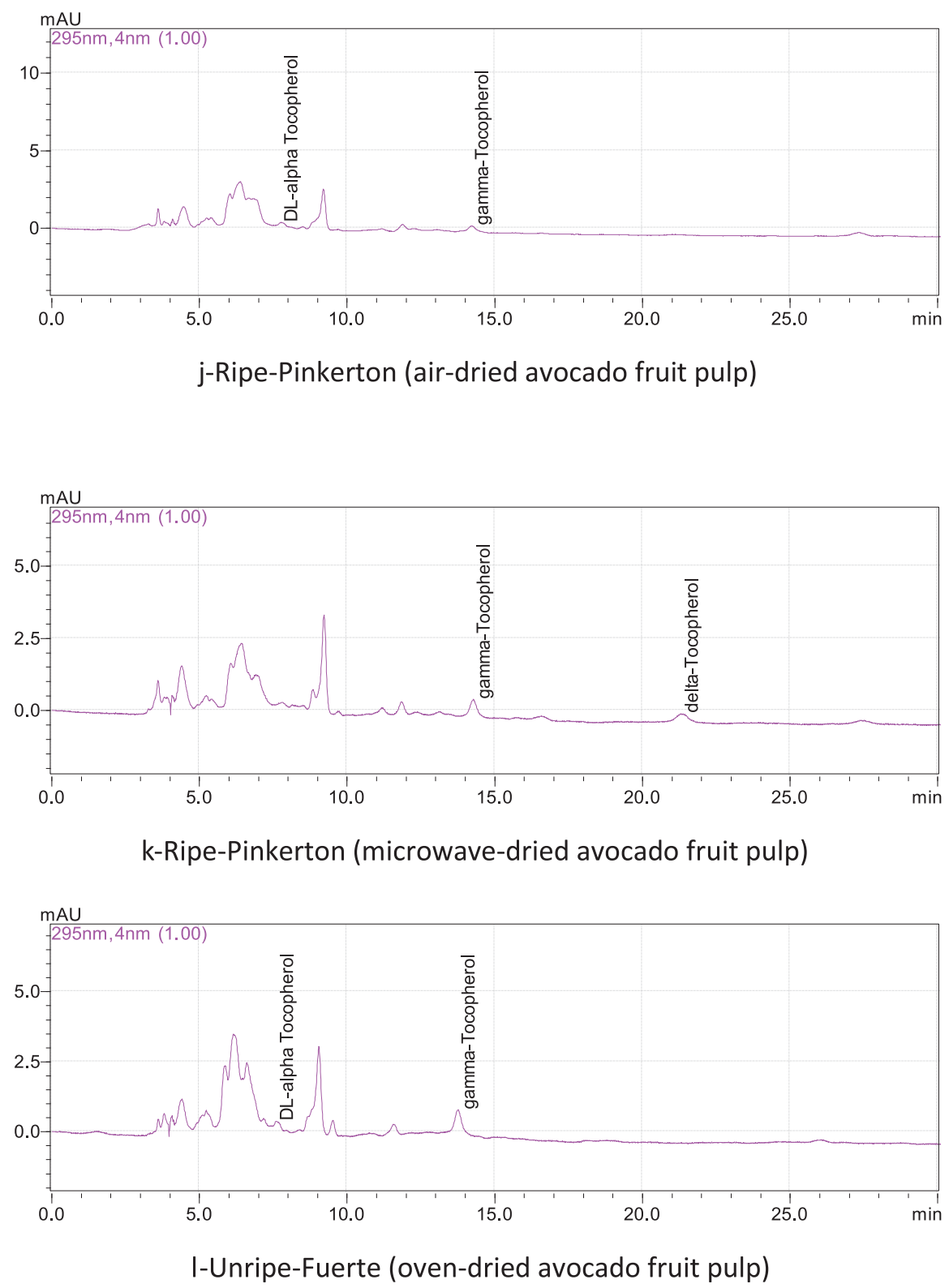

Fig. 1 Continued. 

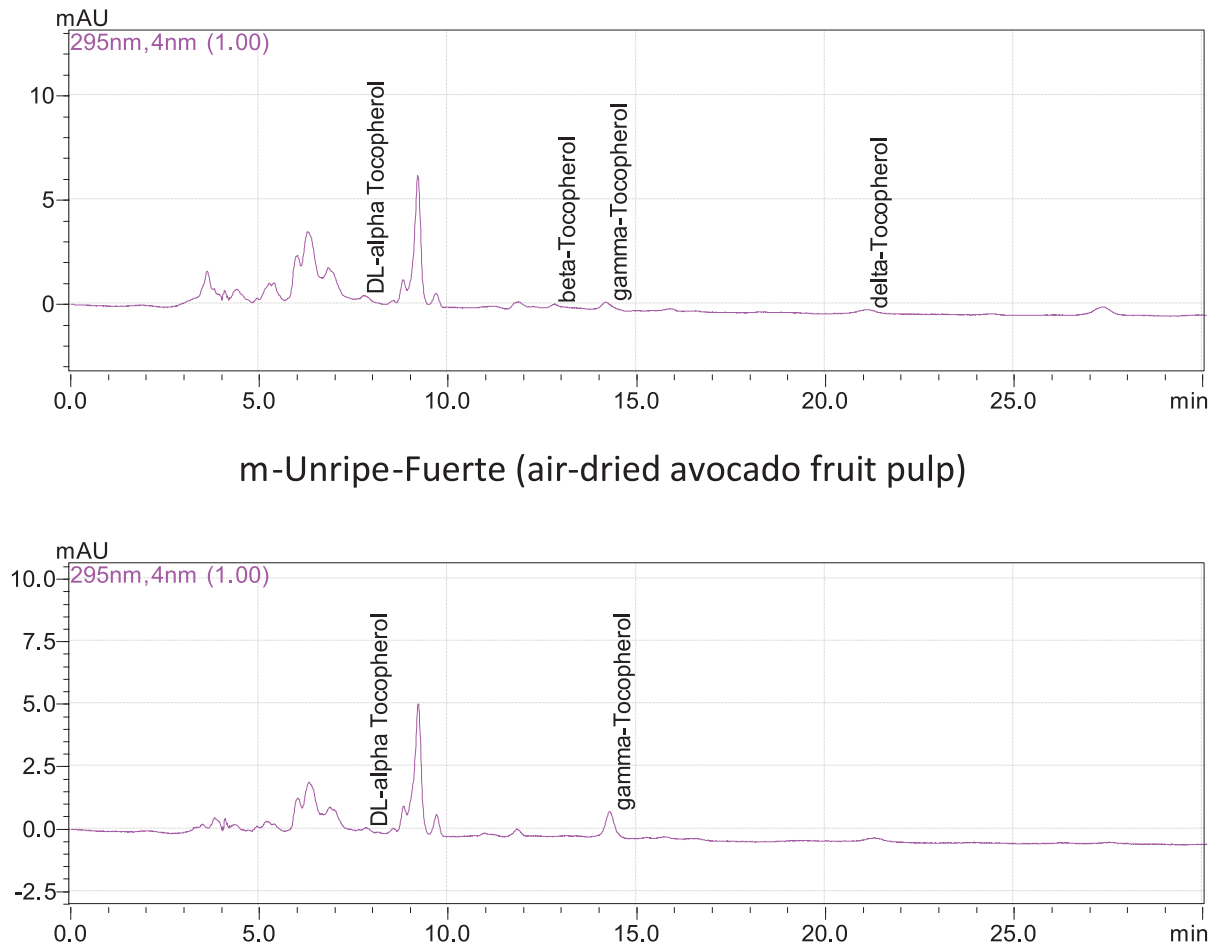

n-Unripe-Fuerte (microwave-dried avocado fruit pulp)

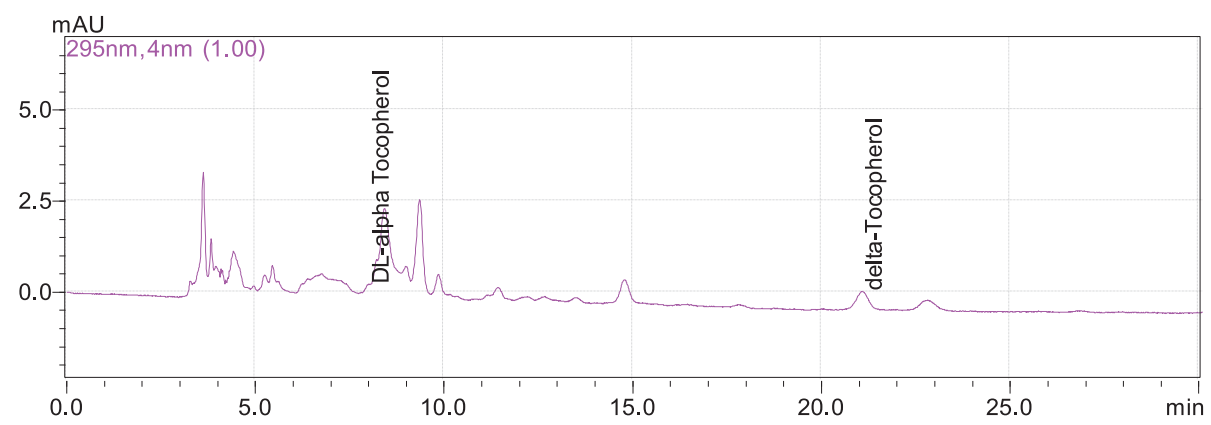

o-Unripe-Fuerte (control, fresh avocado fruit pulp)

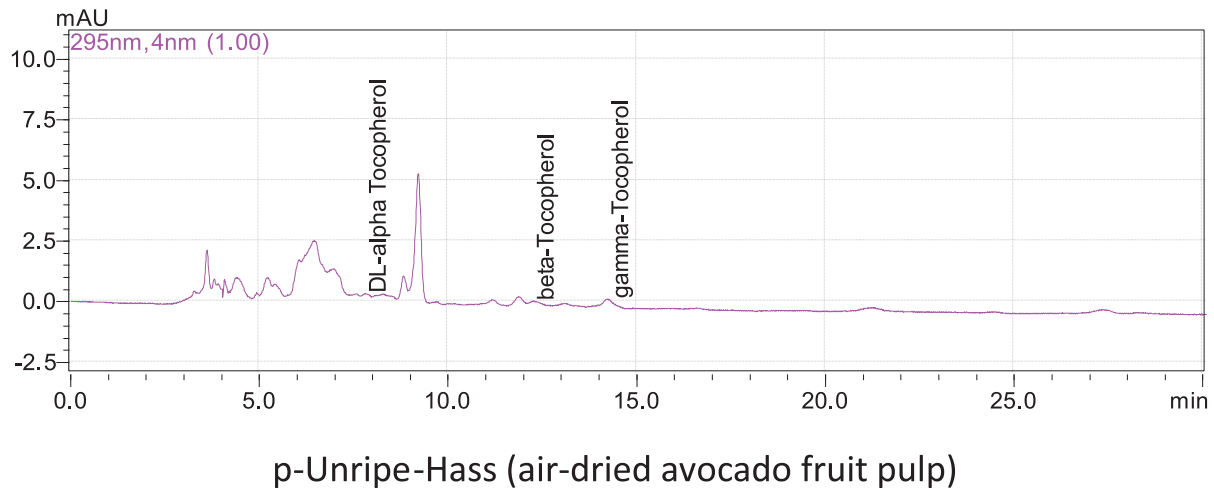

Fig. 1 Continued. 


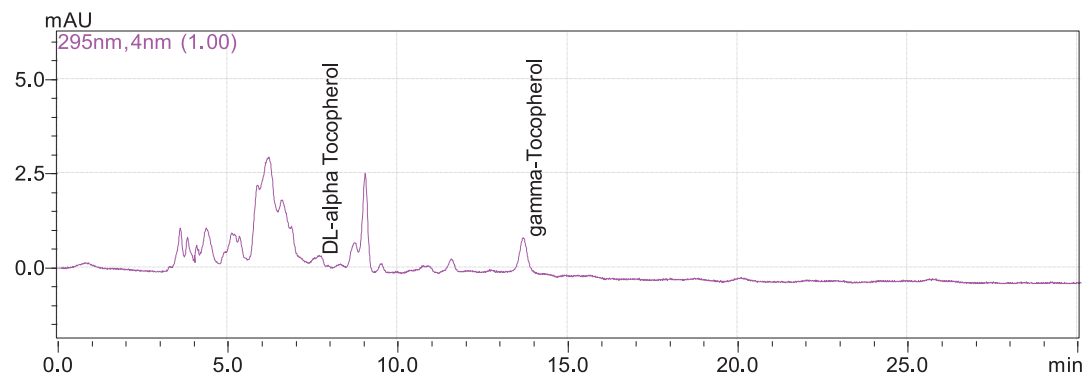

q-Unripe-Hass (microwave-dried avocado fruit pulp)

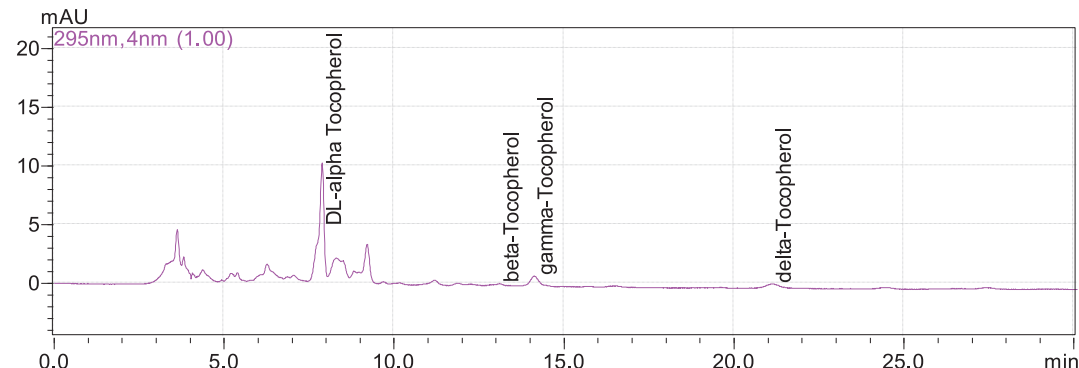

r-Unripe-Hass (control, fresh avocado fruit pulp)

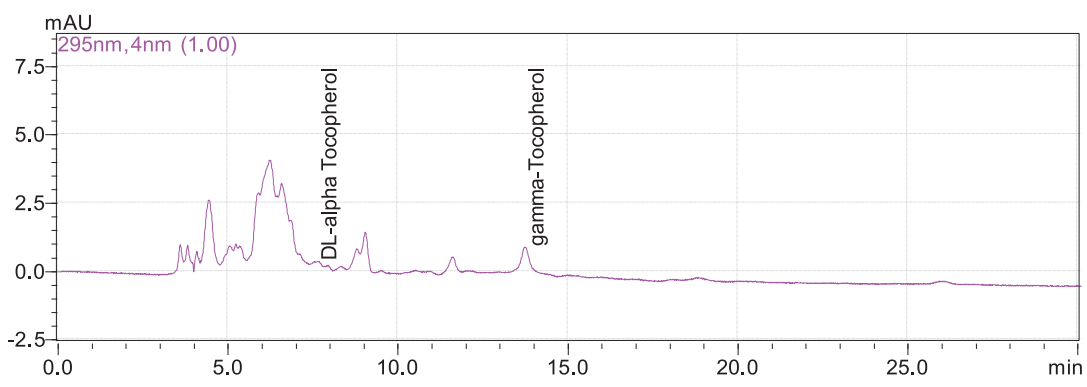

s-Unripe-Pinkerton (oven-dried avocado fruit pulp)

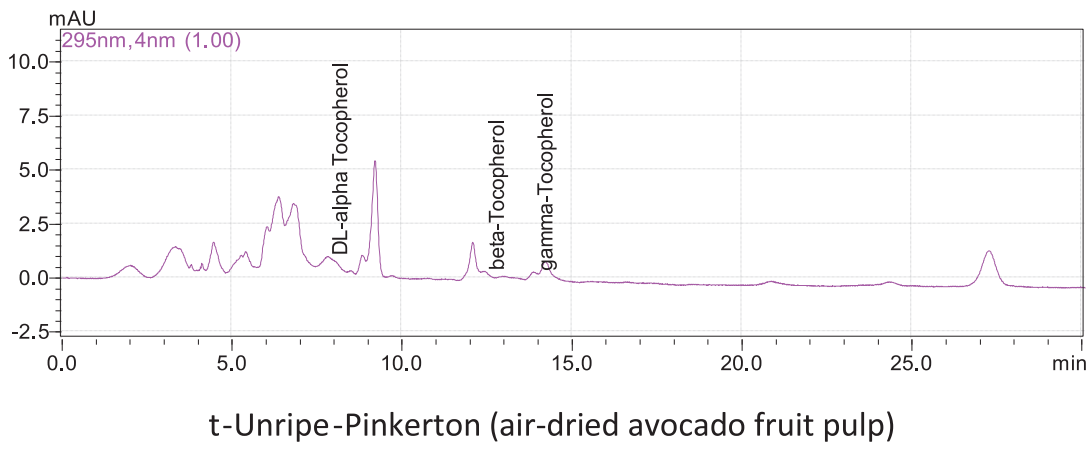

Fig. 1 Continued. 

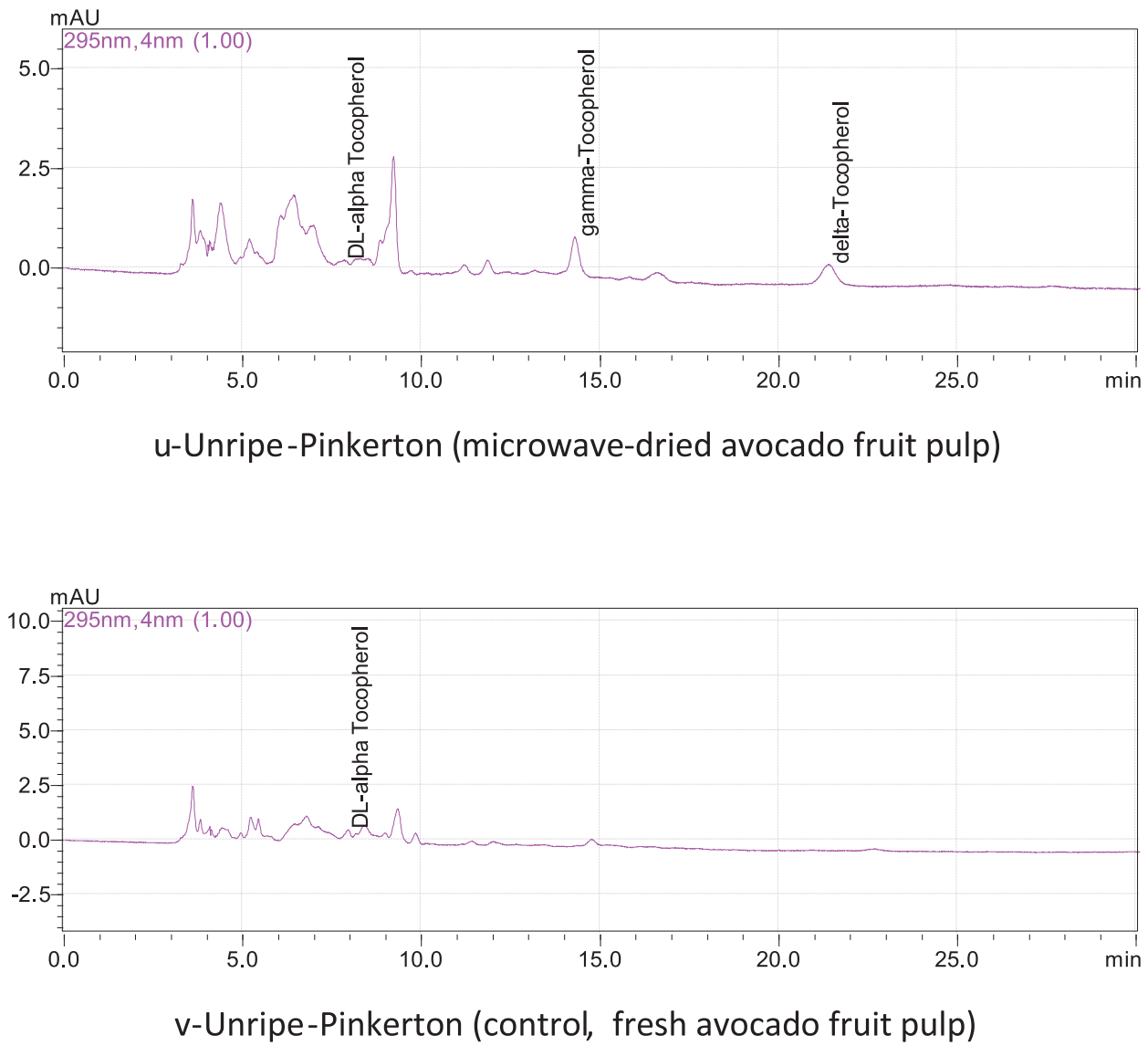

Fig. 1 Continued.

studies may also help in identifying the appropriate drying technique using a range of process time and temperature and in relation to other nutrients present in avocado fruit pulp.

\section{Acknowledgements}

The authors would like to extend their sincere appreciation to the Deanship of Scientific Research at King Saud University for its funding the Research group NO (RG1435-049).

\section{References}

1) Sinyinda, S.; Gramshaw, J.W. Volatiles of avocado fruit. Food Chem. 62, 483-487 (1998).

2) Galvao, M.dD.S.; Narain, N.; Nigam, N. Influence of different cultivars on oil quality and chemical characteristics of avocado fruit. Food Sci. Technol. 34, 539-546 (2014)

3) Afahakan, M.; Umar, I.; Inuwa-Hajiya, M.; Zubairu, M.; Dawud, F. Hypolipidemic and antioxidant effects of petroleum ether and methanolic fraction of Persea americana Mill. seed in wistar rats fed a high fat-high cholesterol diet. Int. J. Med. Pharm. Sci. 3, 1-10 (2013).

4) Gomez-López, V. Fruit characterization of high oil avocado varieties. Sci. Agric. 59, 403-406 (2002).

5) Villa-Rodríguez, J.A.; Molina-Corral, F.J.; Ayala-Zavala, J.F.; Olivas, G.I.; González-Aguilar, G.A. Effect of maturity stage on the content of fatty acids and antioxidant activity of 'Hass' avocado. Food Res. Int. 44, 1231-1237 (2011).

6) Dreher, M.L.; Davenport, A.J. Hass avocado composition and potential health effects. Crit. Rev. Food Sci. Nutr. 53, 738-750 (2013).

7) Daiuto, E.R.; Vieites, R.L.; de Carvalho, L.R.; Simon, J.W.; Russo, V.C. Sensory analysis of cold-stored guacamole added with $\alpha$-tocopherol and ascorbic acid. Revista Ceres 58, 140-148(2011).

8) Weschenfelder, C.; dos Santos, J.L.; de Souza, P.A.L.; de Campos, V.P.; and Marcadenti, A. 2015. Avocado and cardiovascular health. Open J. Endocr. Metabol. Dis. 5, 77-83 (2015).

9) Yasir, M.; Das, S.; and Kharya, M.D. The phytochemical and pharmacological profile of Persea americana 
Mill. Pharmacog. Rev. 4, 77-84(2010).

10） Lu, Q.-Y.; Arteaga, J.R.; Zhang, Q.; Huerta, S.; Go, V.L. W.; Heber, D. Inhibition of prostate cancer cell growth by an avocado extract: Role of lipid-soluble bioactive substances. J. Nutr. Biochem. 16, 23-30 (2005).

11) Akpinar, E.K.; Bicer, Y. Modelling of the drying of eggplants in thin-layers. Int. J. Food Sci. Technol. 40, 273-281 (2005).

12) Spica, M.J.; Kraljic, K.; Koprivnjak, O.; Skevin, D.; Zanetic, M.; Katalinic, M. Effect of agronomical factors and storage conditions on the tocopherol content of Oblica and Leccino virgin olive oil. J. Am. Oil Chem. Soc. 92, 1293-1301 (2015).

13) Püskülcü, H.; İkiz, F. Introduction to Statistic. Bilgehan Press. Bornova, İzmir, Turkey p.333(1989). (in Turkish).

14) Peraza-Magallanes, A.Y.; Pereyra-Camacho, M.A.; Sandoval-Castro, E.; Medina-Godoy, S.; Valdez-Morales, M.; Clegg, M.T.; Calderon-Vázquez, C.L. Exploring genetic variation, oil and $\alpha$-tocopherol content in avocado (Persea americana) from northwestern Mexico. Genet. Resour Crop Evol. 64, 443-449 (2017).

15) dos Santos, M.A.Z.; Alicieo, T.V.R.; Pereira, C.M.P.; Ramis-Ramos, G.; Carla, R.B.; Mendonc, C.R.B. Profile of bioactive compounds in avocado pulp oil: Influence of the drying processes and extraction methods. J. Am. Oil. Chem. Soc. 91, 19-27(2014).

16) Saldeen, K.; Saldeen, T. Importance of tocopherols beyond $\alpha$-tocopherol: Evidence from animal and human studies. Nutr. Res. 25, 877-889(2005).

17) Murcia, M.A.; Jimenez, A.M.; Martinez-Tome, M. Evaluation of the antioxidant properties of Mediterranean and tropical fruits compared with common food additives. J. Food Protect. 64, 2037-2046 (2001).

18) Guzman-Geronimo, R.I.; Lopez, M.G.; Dorantes-Alvarez, L. Microwave processing of avocado: Volatile flavor profiling and olfactometry. Innov. Food Sci. Emerg. Technol. 9, 501-506(2008).

19) Deiana, M.; Rosa, A.; Cao, C.F.; Pirisi, F.M.; Bandino, G.; Dessi, M.A. Novel approach to study oxidative stability of extra virgin olive oils: Importance of $\alpha$-tocopherol concentration. J. Agric. Food Chem. 50, 4342-4346 (2002)

20) Wang, S.; Hwang, H.; Yoon, S.; Choe, E. Temperature dependence of autoxidation of perilla oil and tocopherol degradation. J. Food Sci. 75, 498-504(2010).

21) Rodríguez-Carpena, J-G.; Morcuende, D.; Andrade, M-J.; Kylli, P.; Estevez, M. Avocado (Persea americana Mill.) Phenolics, in vitro antioxidant and antimicrobial activities, and inhibition of lipid and protein oxidation in Porcine patties. J. Agric. Food Chem. 59, 5625-5635 (2011).

22) Hua-Min Liu, H.-M.; Han, Y.-F.; Wang, N.-N.; Zheng, Y.Z.; Xue-De Wang, X.-D. Formation and antioxidant activity of maillard reaction products derived from different sugar-amino acid aqueous Model systems of sesame roasting. J. Oleo Sci. 69, 391-401 (2020). 